\title{
Article
}

\section{Cool Roofs in the US: The Impact of Roof Reflectivity, Insulation and Attachment Method on Annual Energy Cost}

\author{
Athanasios Tzempelikos ${ }^{1,2, *(1)}$ and Seungjae Lee $^{3}$ \\ 1 Lyles School of Civil Engineering, Purdue University, West Lafayette, IN 47907, USA \\ 2 Center for High Performance Buildings, Ray W. Herrick Laboratories, Purdue University, \\ West Lafayette, IN 47907, USA \\ 3 Department of Civil \& Mineral Engineering, University of Toronto, Toronto, ON M5S 1A4, Canada; \\ sjae.lee@utoronto.ca \\ * Correspondence: ttzempel@purdue.edu
}

check for updates

Citation: Tzempelikos, A.; Lee, S. Cool Roofs in the US: The Impact of Roof Reflectivity, Insulation and Attachment Method on Annual Energy Cost. Energies 2021, 14, 7656. https://doi.org/10.3390/en14227656

Academic Editors: Giovanni Pernigotto and Francesco Nocera

Received: 30 September 2021 Accepted: 10 November 2021 Published: 16 November 2021

Publisher's Note: MDPI stays neutral with regard to jurisdictional claims in published maps and institutional affiliations.

Copyright: (c) 2021 by the authors. Licensee MDPI, Basel, Switzerland. This article is an open access article distributed under the terms and conditions of the Creative Commons Attribution (CC BY) license (https:// creativecommons.org/licenses/by/ $4.0 /)$.

\begin{abstract}
While it is well-known that cool roofs can efficiently reduce cooling demand in buildings, their overall energy performance in mixed and cold climates has been a topic of debate. This paper presents a comprehensive simulation study to evaluate the combined impact of roof reflectivity, insulation level, and construction type (adhered vs attached) on annual energy demand and energy costs in the United States, for different buildings and climate zones. EnergyPlus was used to model three building types (retail, office, and school buildings) for the 16 most climate-representative locations in the US using typical reflectivity and insulation values. The results show that (i) roof reflectivity is equally important to roof insulation in warm climates; (ii) for low-rise offices and schools, the benefits of reflective roofs vs dark-colored roofs are clear for all US climatic zones, with higher savings in warm climates; (iii) for big-box-retail buildings, reflective roofs perform better except for cold climate zones 7-8; (iv) dark-colored, mechanically attached roofs achieve slightly better performance than reflective roofs in mixed and cold climates. Decision makers should consider building type, climatic conditions, roof insulation levels, and durability performance, along with roof reflectivity, when assessing the overall potential benefits of cool roofs.
\end{abstract}

Keywords: cool roofs; adhered roofs; mechanically attached roofs; building energy modeling; thermal performance; insulation; energy cost savings

\section{Introduction}

Cool and reflective roofs can decrease roof surface temperatures and building cooling load. Consequently, they can contribute to reducing radiative heat flux to the atmosphere, which may potentially mitigate the urban heat island effect at a city scale [1-4]. The benefits of cool roofs in warm climates have not been questioned. However, recent reports have expressed concerns about their overall energy impact in mixed and cold climates, where heating is a significant part of the building energy use, and dark roofs are considered more effective. In addition, different tools and calculators provide different and confusing results with respect to cool roof energy performance in different climates. A review on the overall efficiency of reflective roofs and questions about their applicability and effectiveness in specific climates are presented below.

\subsection{Studies Supporting the Potential Benefits of Reflective Roofs in Different Climates}

Several studies evaluated the impact of reflective roofs (i.e., with reflectivity higher than $50 \%$ for aged samples) on the cooling potential for buildings, neighborhoods, and even entire cities. Most of these studies are summarized in an excellent review by Santamouris [5]. The cooling benefits and improvements in indoor thermal conditions for different climates (e.g., New York City, California cities, London, UK, and various locations in Greece, Italy, Spain, and France) have been the focus of recent research [6-16]. All these studies in 
different climates around the world show that reflective roofs result in energy savings and reduced surface and indoor air temperatures, depending on climatic conditions and building characteristics. In London, the optimum roof reflectivity for achieving energy savings was $0.6-0.7$ [13]. Mastrapostoli et al. [17] measured 73\% cooling savings and 5\% heating penalty using cool fluorocarbon coatings on the roof of an industrial building located in Oss, Netherlands. The direct benefits of cool roofs in urban settings were investigated by [11] in the Metropolitan Hyderabad region in India. The measured annual energy savings from roof whitening of previously black roofs ranged from $20-22 \mathrm{kWh} / \mathrm{m}^{2}$ of roof area, corresponding to a cooling energy use reduction of $14-26 \%$. The application of white coatings to uncoated concrete roofs resulted in annual savings of $13-14 \mathrm{kWh} / \mathrm{m}^{2}$ of roof area, corresponding to cooling energy savings of $10-19 \%$.

In the United States, a significant amount of work on this topic was conducted by the Lawrence Berkeley National Laboratory (LBNL) and its Heat Island group, starting in the 1990s. Akbari and Konopacki [18] performed simulations to evaluate the cooling potential of reflective roofs (compared to black roofs) for 11 US cities (several climatic zones) and concluded that the colder the climate, the less the savings. However, surface emissivity plays a significant role as well. They estimated the energy cost savings (per roof unit area) in the range of $\$ 0.05-0.34 / \mathrm{m}^{2}$ depending on climate, except for Philadelphia, where there was a net energy cost deficit per roof area of $\$ 0.02 / \mathrm{m}^{2}$. For commercial buildings specifically, the net savings with cool roofs ranged from $\$ 0.1$ to $\$ 0.35 / \mathrm{m}^{2}$. Assuming an average roof life of 20 years and a 3\% real interest rate, the present value of the savings was about $\$ 0.75-5.25$ per $\mathrm{m}^{2}$ of cool roof unit area compared to a typical black roof.

In a following study [19], they found that switching from a black-colored membrane to a white membrane in a $10,000 \mathrm{~m}^{2}$ retail store in Austin, Texas, decreased the average summertime rooftop surface temperature from $75.5^{\circ} \mathrm{C}$ to $52.2{ }^{\circ} \mathrm{C}$. This resulted in peak hour cooling energy savings of $14 \%$ and overall annual energy savings of $\$ 0.75 / \mathrm{m}^{2}$ of roof area. Adjusted for inflation, this would be the equivalent of more than $\$ 1 / \mathrm{m}^{2}$ today. In their following study in Toronto, Canada, the authors concluded that reflective roofs may result to savings up to $20 \%$ for that cold climate. Recently, Sproul et al. (2014) conducted an energy and economic comparison between white, green, and black flat roofs in the US and found that white roofs may lead to impressive net unit area savings of $\$ 25 / \mathrm{m}^{2}$ compared to black roofs over a 50-year life cycle.

\subsection{Debating the Drawbacks of Reflective Roofs in Mixed and Cold Climates}

The advantages of reflective roofs in warm climates are not in question. Some of the studies mentioned above emphasize the benefits of reflective roofs for mixed and even cold climates. However, a few recent reports question the efficiency of reflective roofs in such cases. An article by the EPDM Roofing Association [20] challenges the findings by Sproul et al. [21], claiming that the study "disregarded evidence supporting black roofs over white roofs in terms of geographical climate differences, insufficient data, human health advantages, cleaning of roofs, life of roofs, and that the study was nonreproducible". Similarly, other reports [22] state that the LBNL study "did not consider acceptable insulation levels, construction assemblies common in cold regions, winter time air quality degradation and solar gain positive effects in winter".

Indeed, the amount of insulation and building characteristics play a major role in the overall performance of reflective roofs. However, several scientific studies support the benefits of cool roofs in various North American locations (all climates) and for different building types. In one of the most extensive studies, Levinson and Akbari [23] estimated the potential benefits of reflective roofs for commercial buildings in 236 US cities. They found out that, in all locations except for remote sites in Alaska, summertime cooling energy savings offset any heating energy penalty, resulting in net annual energy savings. Energy savings per roof area ranged from $\$ 0.126 / \mathrm{m}^{2}$ in West Virginia to $\$ 1.14 / \mathrm{m}^{2}$ in Arizona, averaging $\$ 0.356 / \mathrm{m}^{2}$ nationwide based on the studied locations. Taylor and Hartwig [24] considered energy costs including demand charges in several US locations 
and showed that converting from a dark, absorptive roof membrane to a highly reflective cool roof will result in overall energy savings in all locations regardless of local climate in the US.

In another study, the DOE-2 simulation tool was used to simulate the energy consumption of a $465 \mathrm{~m}^{2}$-office building in Anchorage, Alaska [25]. The annual heating energy consumption was not much different with dark and white roofs, 0.85 and $0.88 \mathrm{MJ} / \mathrm{m}^{2}$ respectively, without considering the snow effects. Including the effect of late-winter packed snow, the respective numbers were reduced by 2-5\%. A report from Graveline [26] confirms that Target Stores, with approximately 2000 stores in all climate zones of the US, started shifting from dark to reflective roofs 20 years ago and have reported net positive energy impact from reflective roofs, even in locations with lengthy heating seasons. The few "non-cool" dark roofs in stores located in northern climates have not shown any measurable reduction in energy consumption compared to cool roofs in similar climates.

\subsection{Cool Roof Calculators-Revisiting Results for Mixed and Cold Climates}

Some of the reports, claiming that reflective roofs have negative effects in cold climates, support their findings on results obtained from available simple web tools with easy graphical user interfaces. The Cool Roof Calculator [27] is a simple graphical interface for comparing the energy performance of buildings with different types of roof finish/reflectivity (i.e., reflective vs dark) and insulation levels, for different climates and utility costs. The tool is "agnostic to the building type and basically a metric of minimum benefits", as confirmed by Pearson [28]. Therefore, detailed building characteristics, internal gains, etc. are not taken into account. Nevertheless, the tool is useful, since it provides a basic idea of what to expect when planning to replace existing roofs or installing new roofs. Reale [29] used the Cool Roof calculator and reported that dark-colored roofs result in lower energy use in northern climates, due to more heating degree days and higher percentage of energy used for heating. These findings are not aligned with the results of previous research studies or with some of the results of the tool itself. Pearson includes a statement from the developers of the tool saying that the tool shows that only over climate Zone 6 does the heating penalty outweigh the benefit, and Zones 4 and 5 "are pretty much energy neutral".

The Roof Savings Calculator [30] is another simplified tool developed for the same purpose. Tyler [31] used this interface to simulate a single-story, $4645 \mathrm{~m}^{2}$-office building (with roof insulation equal to $3.5 \mathrm{~m}^{2}{ }^{\circ} \mathrm{C} / \mathrm{W}$ ). He found that reflective roofs result in net energy savings in Miami and Phoenix, whereas there is a net energy loss for Chicago, Philadelphia, Atlanta, Louisville, St. Louis, Boston, and Portland compared to black roofs. Pearce [32] used the same tool for a single-story, $929 \mathrm{~m}^{2}$-building in Boston with the same amount of roof insulation and found a net annual energy cost increase of $\$ 500$ by using a white roof vs a black roof. Moreover, they claimed that locations as far south as Nashville, TN could benefit from black roofing. These results, obtained by the Roof Savings Calculator, are not in agreement with published research studies (or results from the Cool Roof Calculator). Discrepancies with this tool were recognized in 2013 [33], and the Roof Savings Calculator is being revised.

\subsection{Connection between Roof Insulation Level, Climate and Cool Roof Performance}

Climatic conditions, building type and characteristics, and roof insulation all play a significant role when investigating the impact of overall cool roof energy performance. As concluded from the studies reviewed by Santamouris [5]: "Peak summer indoor temperatures may decrease up to $2{ }^{\circ} \mathrm{C}$ in moderately insulated buildings, while cooling loads reductions may range between $10 \%$ and $40 \%$. The corresponding heating penalty for mixed climates may range between $5 \%$ and $10 \% "$. Freund et al. [34] conducted a comprehensive study using TRNSYS to investigate the effect of roof reflectivity for a large retail building with four roof insulation levels (from 0.7 to $4.2 \mathrm{~m}^{2}{ }^{\circ} \mathrm{C} / \mathrm{W}$ ) for the cold climate of Minneapolis. The white roof resulted in 6-17\% lower cooling energy consumption. Although 
the increased heating costs in the winter negate a portion of the cooling savings, the total net annual energy cost savings with the white roof were still positive, in the range of $\$ 0.09-0.3 / \mathrm{m}^{2}$. The same study for Denver, which is a mixed climate, showed potential total savings twice as high. Desjarlais et al. [35] used the Simplified Transient Analysis of Roofs (STAR) model to estimate the additional insulation required for a black roof to achieve energy equivalency with a reflective roof in different locations. Required additional $\mathrm{R}$-values of a black roof ranged from $0.53 \mathrm{~m}^{2}{ }^{\circ} \mathrm{C} / \mathrm{W}$ in Fairbanks, Alaska to $3 \mathrm{~m}^{2}{ }^{\circ} \mathrm{C} / \mathrm{W}$ in Miami, Florida, with an average of $1.58 \mathrm{~m}^{2}{ }^{\circ} \mathrm{C} / \mathrm{W}$ in new construction and $0.7 \mathrm{~m}^{2}{ }^{\circ} \mathrm{C} / \mathrm{W}$ in retrofit applications.

The effect of ageing and roof insulation on spectral solar reflectance and the cooling ability of reflective roofs was evaluated experimentally and using modeling by Paolini et al. [36] They found that the reduction of roof reflectivity due to ageing (from 0.8 to around 0.6) results in reduced cooling load savings, ranging from $14 \%$ to $23 \%$ in Rome and $20-34 \%$ in Milan, Italy, depending on insulation levels and other factors. More specifically, a $10 \%$ decrease in roof solar reflectivity translates to reduced annual cooling load savings ranging between 4.1 and $7.1 \mathrm{MJm}^{2}$ for highly insulated buildings, and between 70 and $84 \mathrm{MJ} / \mathrm{m}^{2}$ for non-insulated buildings in Rome. Taylor and Hartwig [24] concluded that reflective roofs will result in energy savings for typical big box retail stores in all US climate zones (1-7) with insulation levels aligned with the requirements of ASHRAE Standard 90.1 [37]. Hosseini et al. [38] conducted a large-scale building performance simulation study to evaluate the effect of 14 roof insulation values and 9 solar reflectance values under real weather data and under typical weather data used in building simulation for the cold climate of Montreal. They found that using typical weather data results in a 3-29\% overestimation in predicted energy performance competed to actual weather data, and the higher the roof insulation level, the lower the error in overestimating space conditioning demand. In another study, Ramamurthy et al. [39] studied the interacting influences of roof reflectivity and insulation at annual, seasonal, and diurnal scales, to find the optimum thermal resistance-solar reflectance combination of the roof. Their analysis showed that a $60 \%$ (or higher) reflective roof with insulation level around $1.5 \mathrm{~m}^{2}{ }^{\circ} \mathrm{C} / \mathrm{W}$ would effectively reduce the overall thermal load of buildings in northeastern United States.

\subsection{Contributions and Outline}

In order to answer the questions about the benefits of cool roofs vs black roofs in different climatic zones, this paper presents a detailed modeling study that combines the effect of building characteristics and climatic conditions with the joint effect of roof reflectivity, insulation level, and attachment type. Therefore, the overall impact of cool roofs on annual energy cost is presented as a function of roof insulation for adhered and attached roof systems, separately for each reference building type (retail, office, and schools) in 16 different US climates. We show that the energy performance of cool roofs is related to roof insulation but also depends on the building type in each climate. In this way, informed decisions can be made considering all relevant factors when assessing the energy savings potential of cool roofs.

This paper is outlined as follows. In Section 2, the simulation model is described with required parameters, reference building types, and range of varied reflectivity and insulation values. Section 3 presents the energy demand and cost savings results for adhered reflective roofs, for each building type and climate, also discussing the relative impact of roof insulation and reflectance. In Section 4, a modeling analysis is conducted for flexible (attached) roof systems, for the case of big box retail building. The conclusions of this study are summarized in Section 5.

\section{Materials and Methods}

\subsection{Simulation Study Description and Modeling Parameters}

The whole building analysis tool EnergyPlus [40] was used to obtain reliable results and avoid significant modeling assumptions with simplified tools. EnergyPlus performs a 
dynamic thermal analysis including the effects of solar radiation, internal gains, occupancy schedules, and transient heat transfer through the building envelope for the entire year. These parameters are important to consider when estimating the influence of a reflective roof (or any other envelope system) on overall building energy demand for space conditioning. The analysis was undertaken using TMY 3-hourly weather data for 16 selected locations (Table 1), which cover the entire range of climatic conditions (including ASHRAE climatic sub-zones) in the US (Figure 1) according to ASHRAE [37]. Electricity was used for cooling and natural gas was used for heating the buildings in all locations. Table 1 lists the respective average commercial price for electricity and natural gas in each location based on the US Energy Information Administration [41].

Table 1. Selected cities and energy prices for each location.

\begin{tabular}{|c|c|c|c|}
\hline US Climatic Zone & City/State & $\begin{array}{l}\text { Electricity Cost } \\
(\$ / \text { Kwh) }\end{array}$ & $\begin{array}{c}\text { Natural Gas Cost } \\
\left(\$ / \mathrm{m}^{3}\right)\end{array}$ \\
\hline $1 \mathrm{~A}$ & Miami, Florida & 0.10 & 0.37 \\
\hline $2 \mathrm{~A}$ & Houston, Texas & 0.08 & 0.24 \\
\hline $2 \mathrm{~B}$ & Phoenix, Arizona & 0.10 & 0.33 \\
\hline $3 \mathrm{~A}$ & Atlanta, Georgia & 0.10 & 0.35 \\
\hline $3 \mathrm{~B}$ & Los Angeles, California & 0.13 & 0.25 \\
\hline $3 B$ & Las Vegas, Nevada & 0.09 & 0.27 \\
\hline $3 C$ & San Francisco, California & 0.13 & 0.25 \\
\hline $4 \mathrm{~A}$ & Baltimore, Maryland & 0.10 & 0.36 \\
\hline $4 \mathrm{~B}$ & Albuquerque, New Mexico & 0.09 & 0.22 \\
\hline $4 \mathrm{C}$ & Seattle, Washington & 0.08 & 0.35 \\
\hline $5 \mathrm{~A}$ & Chicago, Illinois & 0.08 & 0.28 \\
\hline $5 \mathrm{~B}$ & Boulder, Colorado & 0.09 & 0.27 \\
\hline $6 \mathrm{~A}$ & Minneapolis, Minnesota & 0.09 & 0.23 \\
\hline $6 \mathrm{~B}$ & Helena, Montana & 0.09 & 0.29 \\
\hline $7 \mathrm{~A}$ & Duluth, Minnesota & 0.09 & 0.23 \\
\hline $8 \mathrm{~A}$ & Fairbanks, Alaska & 0.15 & 0.29 \\
\hline
\end{tabular}

\subsection{Building Types and Characteristics}

To consider the effect of building characteristics on the overall impact of reflective roofs on annual space conditioning energy demand and cost, three building types were modeled: a "big box" retail store, an office building, and an elementary school. According to EIA [41], the current total commercial floor space in the US is around 9 billion $\mathrm{m}^{2}$. Warehouse retail buildings account for 1.4 billion $\mathrm{m}^{2}$, office buildings account for about 1.8 billion $\mathrm{m}^{2}$, and educational buildings account for about 1.3 billion $\mathrm{m}^{2}$ of floor space in the US. Therefore, these general types of buildings cover almost half of the total commercial building stock—it is expected that this percentage will increase by 2050 [41]—and they are good representative buildings of sufficient quantity for analyzing the impact of cool roofs.

These buildings have different envelope characteristics, occupancy schedules and internal gains. To select the most representative building characteristics from each building type, DOE "reference" buildings were used [42] with simple modifications in building size of floor numbers as required. Details and methods on obtaining reference buildings, as well as additional modeling elements can be found in [43]. The selected 16 locations achieve a balance between the climate representation of each zone (including both the effects of ambient temperature and solar gains) and the number of buildings in each climate zone. Using reference buildings also ensures reliability of results, since basic EnergyPlus models for reference buildings have been previously modeled and tested. 


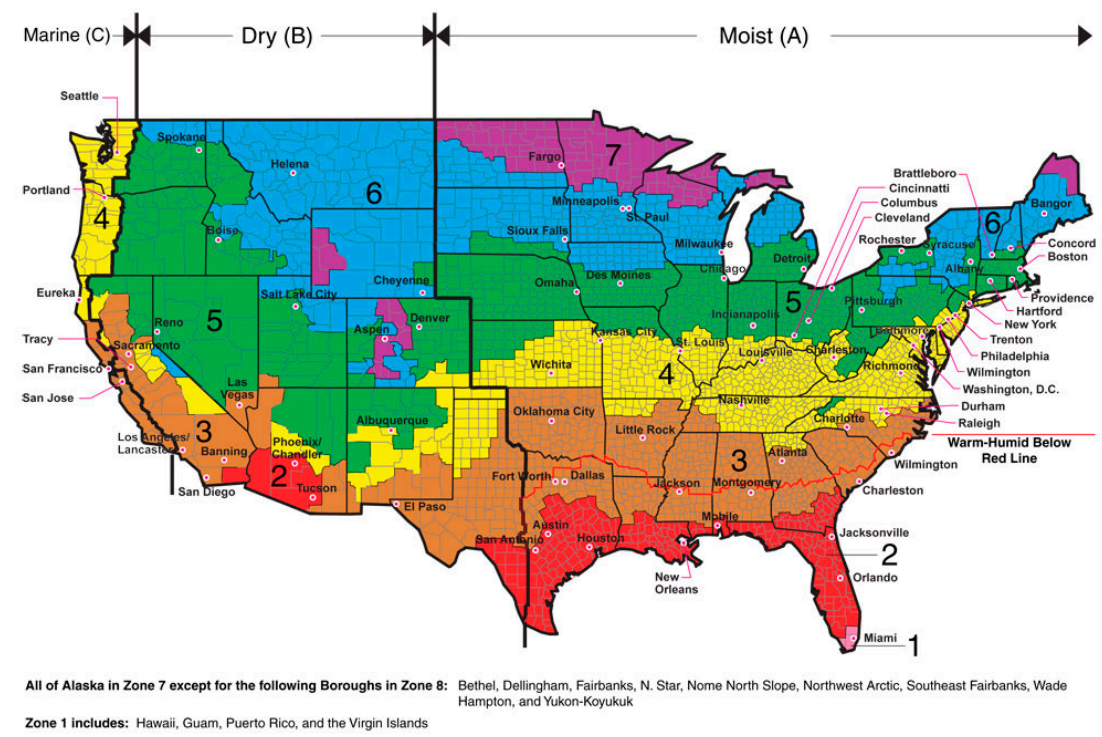

Figure 1. US climatic zones and sub-zones with main cities located in each zone. Reproduced from [37] (ASHRAE, 2017).

Figure 2 presents schematics of the three reference buildings. All three buildings have a flat adhered roof, with the roof membrane on top, insulation below it, and a steel deck at the bottom. Office buildings with a concrete deck were also modeled as discussed later. The same window-to-wall ratio and wall thermal resistance $\left(2 \mathrm{~m}^{2}{ }^{\circ} \mathrm{C} / \mathrm{W}\right.$ according to climatic zone 4 specifications according to ASHRAE 90.1, [37]) were used for all locations, to isolate the clear impact of roof insulation and reflectivity on energy demand (although higher wall insulation levels are recommended for colder climates). Aggregated heating and cooling energy demand was calculated for each zone in every scenario, and the annual space conditioning energy use was calculated assuming cooling system COP equal to 3.5 and heating system efficiency equal to 0.85 . These are common system efficiencies in the US. The total annual cost for space conditioning was calculated using the respective energy prices listed in Table 1 . The basic characteristics for each building type are shown in Table 2.

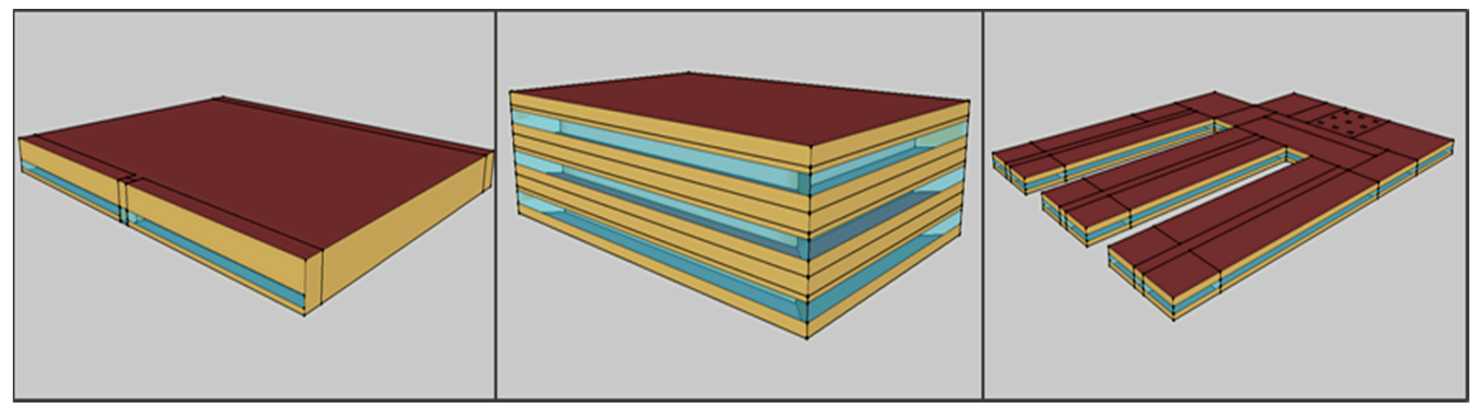

Figure 2. Reference buildings used in the simulation. Big box retail store (left); Office (middle); and School (right).

For each building type and location, the EnergyPlus models were run as "batch" models using three roof reflectivities $(6 \%, 50 \%$, and $70 \%)$ and five roof insulation levels (from $2 \mathrm{~m}^{2}{ }^{\circ} \mathrm{C} / \mathrm{W}$ to $6.13 \mathrm{~m}^{2}{ }^{\circ} \mathrm{C} / \mathrm{W}$ ), to estimate the joint effect of these parameters on annual heating and cooling energy demand for each case. The annual energy costs were then calculated using the energy prices listed in Table 1. Note that separate peak demand charges, which can be significant for some locations like California, were not considered in this analysis. 
Table 2. Reference building types and basic characteristics.

\begin{tabular}{cccccc}
\hline Building Type & \# of floors & $\begin{array}{c}\text { Roof Area } \\
\left(\mathbf{m}^{\mathbf{2}}\right)\end{array}$ & $\begin{array}{c}\text { Total Building } \\
\left.\text { Floor Area } \mathbf{( m}^{\mathbf{2}}\right)\end{array}$ & $\begin{array}{c}\text { Total Building } \\
\text { Height }(\mathbf{m})\end{array}$ & $\begin{array}{c}\text { Space Conditioning } \\
\text { Schedule }\end{array}$ \\
\hline Big box retail & 1 & 14,000 & 14,000 & 9.1 & $\begin{array}{c}24 \mathrm{~h} \\
7 \text { days per week }\end{array}$ \\
\hline Office & 3 & 1660 & 4980 & 11.9 & $\begin{array}{c}6: 00 \text { am-10:00 pm } \\
\text { weekdays }\end{array}$ \\
\hline School & 1 & 11,600 & 11,600 & 4 & $\begin{array}{c}6: 00 \text { am-9:00 pm } \\
\text { weekdays }\end{array}$ \\
\hline
\end{tabular}

\section{Results and Analysis}

The results of this section show the effects of roof reflectivity and roof insulation for each location and building type for adhered roof construction. A black roof (6\% reflectivity) is used as a base case for comparison. The overall trends are similar: higher roof reflectivity results in lower energy demand and annual energy costs, but there are significant variations between the three building types due to their different characteristics and internal gains. The effects of climate (both ambient temperature and solar radiation levels) are also evident in all cases, with interesting results for mixed and cold climates.

\subsection{Big Box Retail Building}

Reflective roofs on big-box retail stores have positive effects on the energy demand (Figure 3) and annual energy costs (Figure 4) for all locations up to climate zone 6 . The energy savings are naturally higher for warmer climates, but do not strictly follow the order of climatic sub-categories. Phoenix shows the highest annual energy savings: $18.2 \mathrm{kWh} / \mathrm{m}^{2}$ and $\$ 0.48 \$ / \mathrm{m}^{2}$ followed by Miami, Houston, and Los Angeles. More cloudy climates, such as Seattle and San Francisco, result in lower energy savings compared to other cities in "colder" climates, i.e., the effect of solar radiation on the cool roof performance becomes evident in the combined analysis considering all factors. Roof insulation plays a major role, balancing the benefits of cool roofs. Nevertheless, cool roofs are clearly beneficial in terms of overall space conditioning energy savings $\left(\sim 0.1 / \mathrm{m}^{2}\right)$ even for well-insulated roofs $\left(\mathrm{R}=3.5 \mathrm{~m}^{2}{ }^{\circ} \mathrm{C} / \mathrm{W}\right)$ up to climate zone 4 . In general, the results show that reflective roofs offer noticeable energy savings for box retail buildings in mixed climates (zones 3-4), and smaller energy savings for colder climates of zones 5 and even 6 (Seattle, Boulder and Minneapolis) for any insulation level. Therefore, previous claims about the negative effects of reflective roofs for these climates are not justified. Nevertheless, other economic and performance factors should be taken into consideration, such as longevity, durability, insulation levels, and attachment types. For the coldest climates of zones 7 and 8 , cool roofs result in small energy and cost penalties over the year.

Considering that aging and weathering can reduce the solar reflectance of roofing materials, a secondary set of simulations was performed for a reduced roof reflectivity (50\%). This is a reasonable estimate since studies have shown that reflective roofs might retain up to $90 \%$ of their reflectivity when cleaned and washed [44], and the actual reflectivity value can reach $50-60 \%$ after $2-3$ years [36]. The results of Figure 5 show that energy benefits are reduced but are still significant for locations up to climate zone 4 , while there are no overall cost penalties for zones 5 and 6 .

The combined effects of roof reflectivity and insulation levels can be more clearly evaluated when analyzing detailed results for specific locations. The variation of annual heating and cooling demand as a function of roof insulation is presented in Figure 6 for a new reflective roof, an aged reflective roof, and a black roof for the box retail building in two different climates, Phoenix and Chicago. Higher levels of roof reflectivity and roof insulation both decrease overall space conditioning energy demand, for different reasons in the two climates. For the cooling-dominated climate of Phoenix, higher roof insulation reduces excessive heat flux from the outside, thereby reducing cooling load. Increased 
roof reflectivity results in higher reflection of solar gains, thus also reducing the cooling load. The impact of insulation is significant, but the effect of roof reflectivity is important for all insulation levels. For the climate of Chicago, increased roof insulation naturally results in lower heating load, and higher reflectivity decreases the cooling load (which is smaller for this building). Therefore, for this climate, the relative impact of roof reflectivity is reduced compared to the relative effect of roof insulation. For under-insulated roofs, high reflectivity will result in a slight increase in heating requirements. Nevertheless, that increase is offset by the reduction in cooling load, and the overall effect of cool roofs is positive for all insulation levels on a yearly basis.

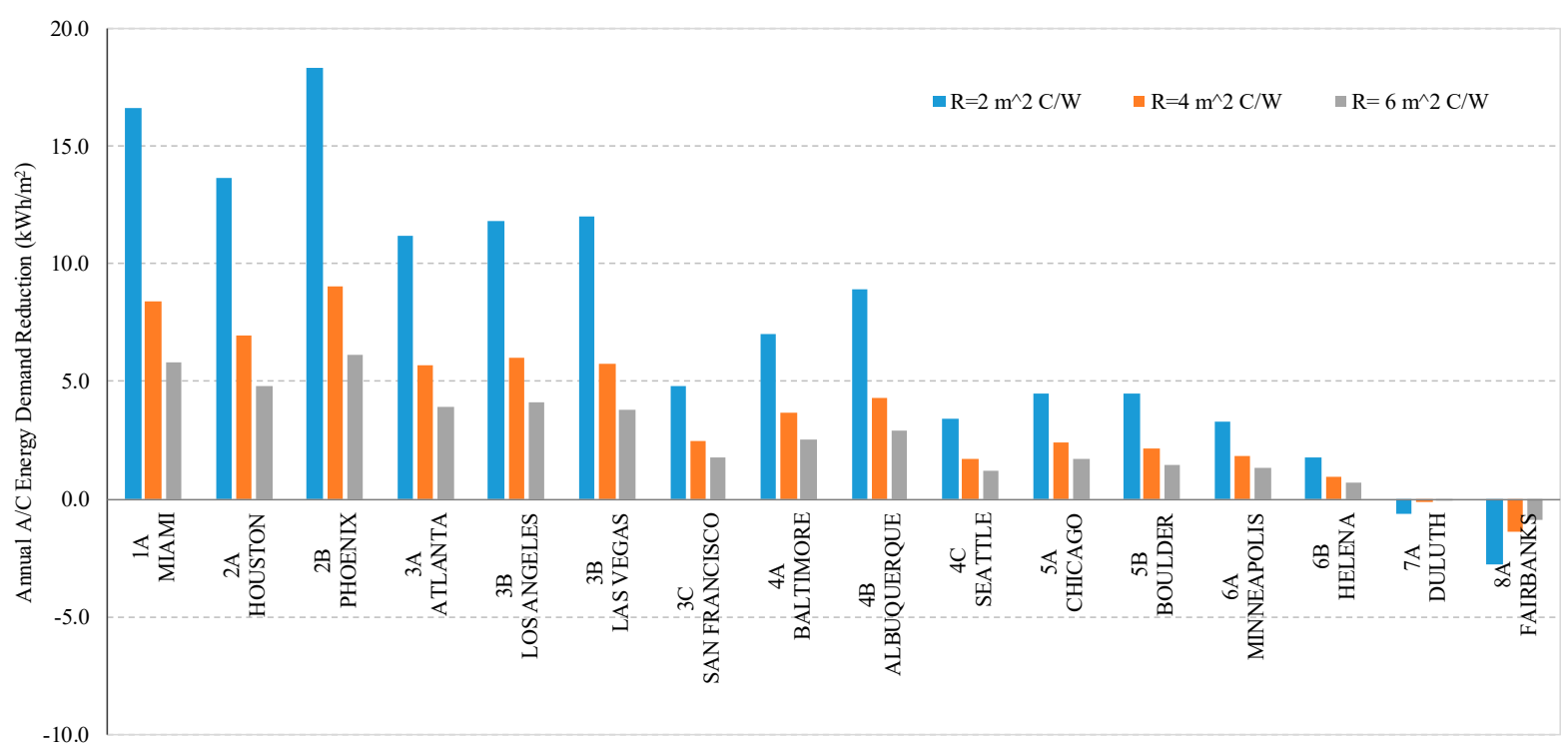

Figure 3. Annual energy demand savings (per unit roof area) with a new reflective roof (70\% reflectivity) versus a black roof ( $6 \%$ reflectivity) for the big box retail store with three roof insulation levels in all 16 climatic locations.

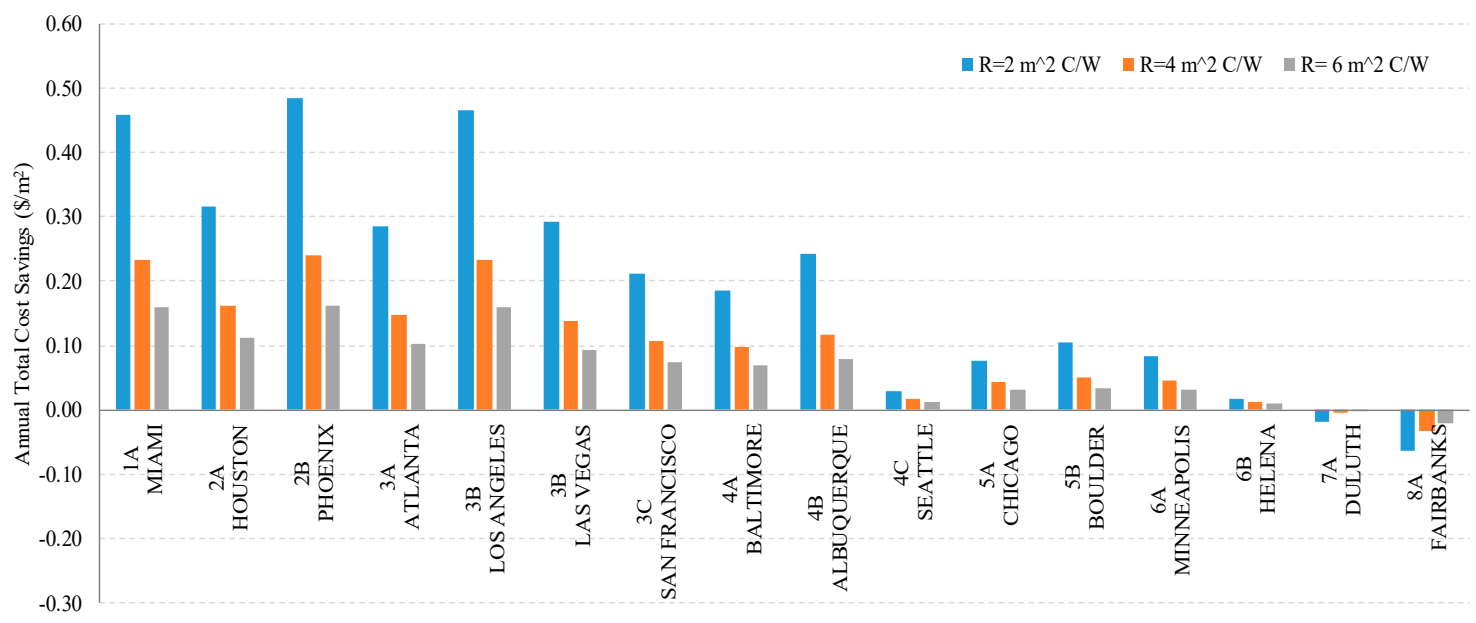

Figure 4. Annual energy cost savings (per unit roof area) with a new reflective roof (70\% reflectivity) versus a black roof (6\% reflectivity) for the big box retail store with three roof insulation levels in all 16 climatic locations. 


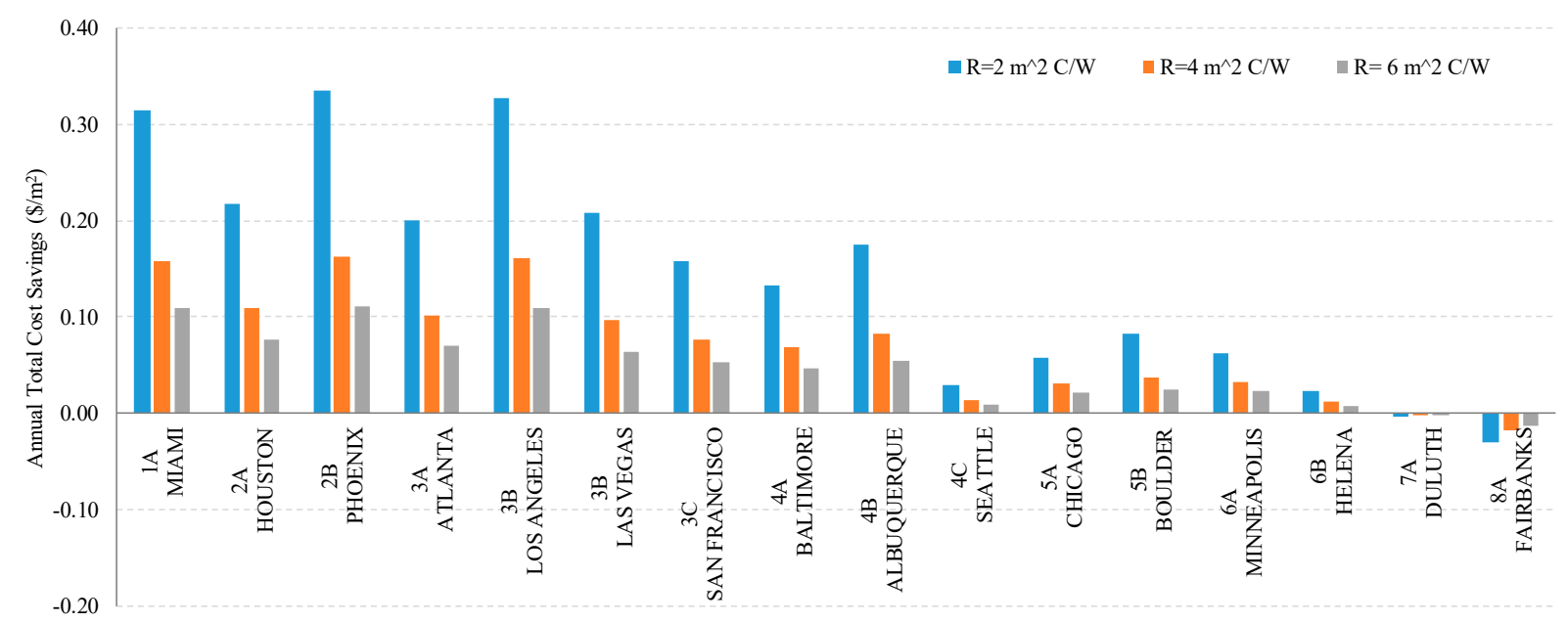

Figure 5. Annual energy cost savings (per unit roof area) with an aged reflective roof (50\% reflectivity) versus a black roof ( $6 \%$ reflectivity) for the big box retail store with three roof insulation levels in all 16 climatic locations.
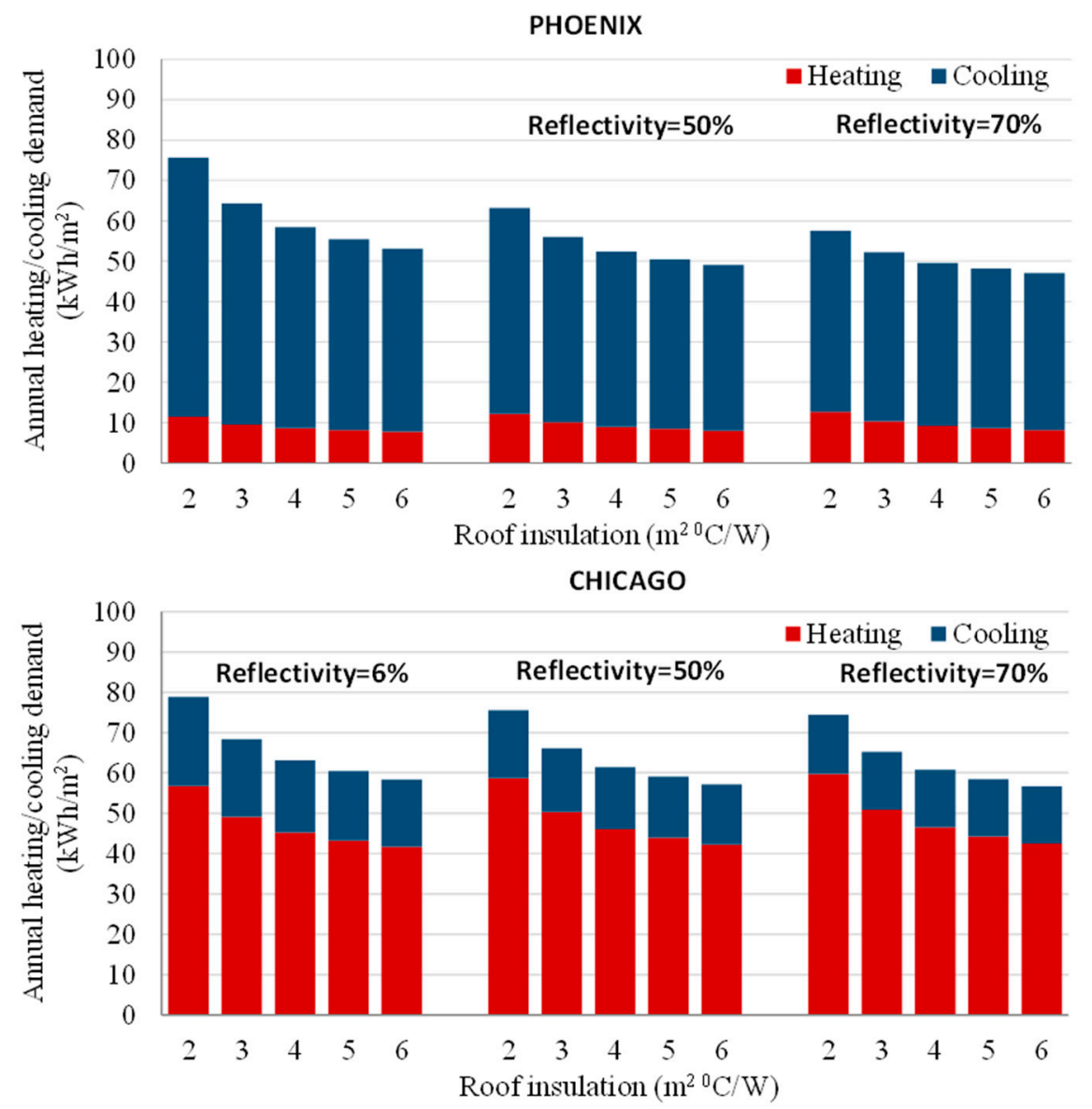

Figure 6. Variation of annual heating and cooling demand of a big box retail building with black roof, aged reflective roof and new reflective roof as a function of roof insulation in Phoenix (top) and Chicago (bottom).

These results also allow an estimation of the extra insulation levels required for a black roof to meet the performance of a cool roof for the same climate. In Phoenix, an additional thermal resistance (of $\mathrm{R}=2 \mathrm{~m}^{2}{ }^{\circ} \mathrm{C} / \mathrm{W}$ ) is needed to match the demand of a cool roof for low insulation levels. However, the performance of a well-insulated cool roof cannot be matched by installing any additional insulation on a black roof for that climate. In Chicago, 
an additional resistance (of $1 \mathrm{~m}^{2}{ }^{\circ} \mathrm{C} / \mathrm{W}$ on average) is needed on a black roof to perform equivalently to a cool roof.

\subsection{Office Building}

The office building has high window areas and internal gains, and therefore its energy demand characteristics are quite different than the box retail store building. In this case, reflective roofs show benefits for all climatic zones (Figure 7). The annual costs savings per roof unit area are more significant, especially in climatic zones $1-4$. Nonetheless, they reach more than $\$ 0.1 / \mathrm{m}^{2}$ even for cold climates with well-insulated roofs $\left(\mathrm{R}=3.5 \mathrm{~m}^{2}{ }^{\circ} \mathrm{C} / \mathrm{W}\right)$. Los Angeles and Phoenix present the most significant savings in the order of $\$ 0.7 / \mathrm{m}^{2}$. Aged reflective roofs with reflectivity to $50 \%$ will result in reduced energy demand savings by up to $20 \%$.

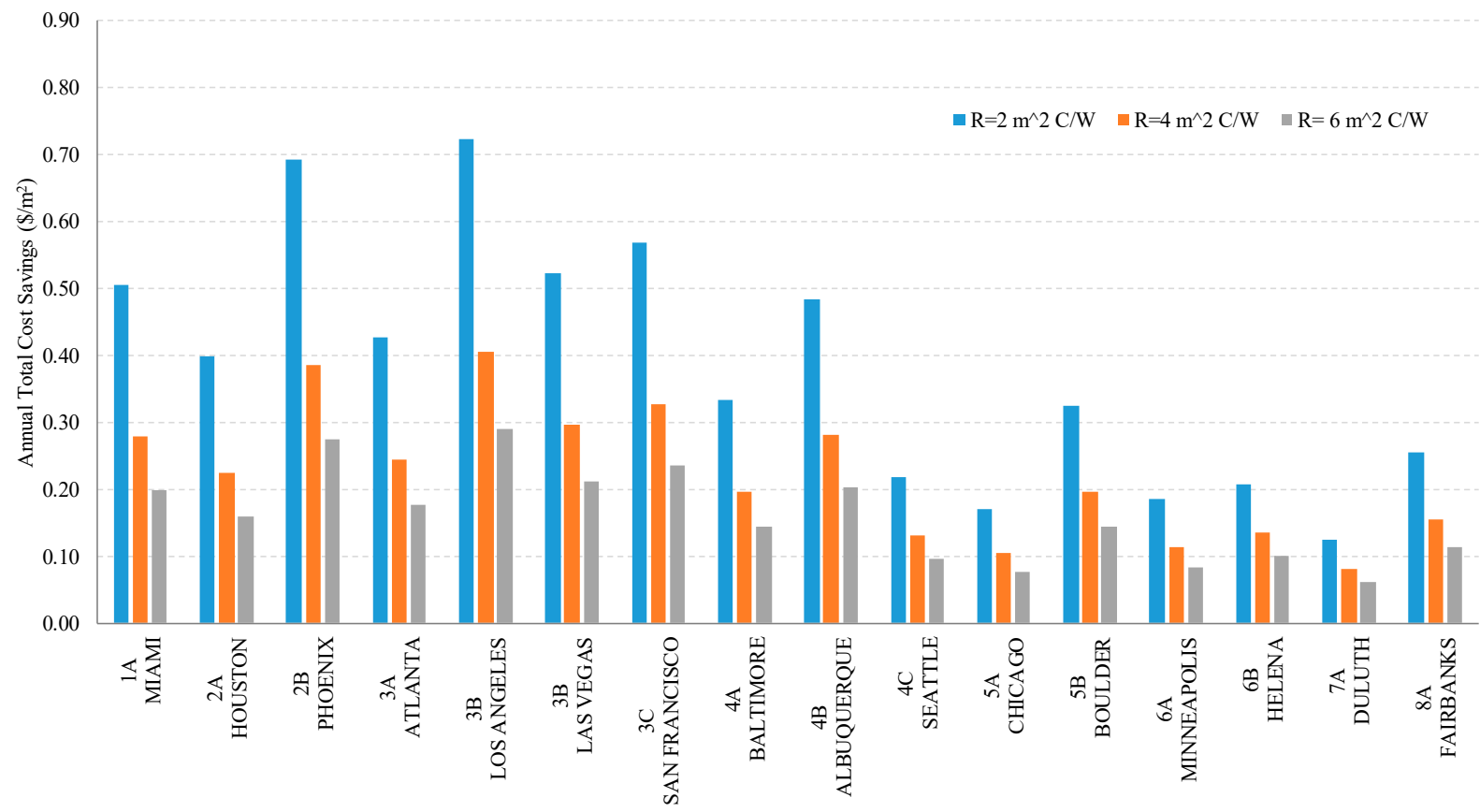

Figure 7. Annual energy cost savings (per unit roof area) with a new reflective roof $(70 \%)$ versus a black roof (6\%) for the office building, with three roof insulation levels in all 16 climatic locations.

The results show that, overall, for typical office buildings, similar to the modeled reference office, there are no penalties from using reflective roofs in any climate. The impact of roof insulation is still significant in all cases. Office buildings with concrete roofs showed similar trends to the steel deck building, with slightly different load profiles due to the concrete thermal mass. The results presented above are in general agreement with the results (Figure 8) presented by Levison and Akbari [23], with small variations in mixed and cold climates, confirming the benefits of reflective roofs for low-rise office buildings in all climatic zones.

An additional analysis was conducted for high-rise office buildings. The impact of a reflective roof on the annual energy cost per unit roof area is similar to the results for the 3-stirey studied office. However, the total building thermal load reduction reduces with the number of floors. A 20-storey office building was modeled after the basic DOE reference office building for that purpose, and the overall reduction in total thermal load (entire building area) for the climate of Phoenix was reduced only by $1 \%$ with a reflective roof vs a black roof. 


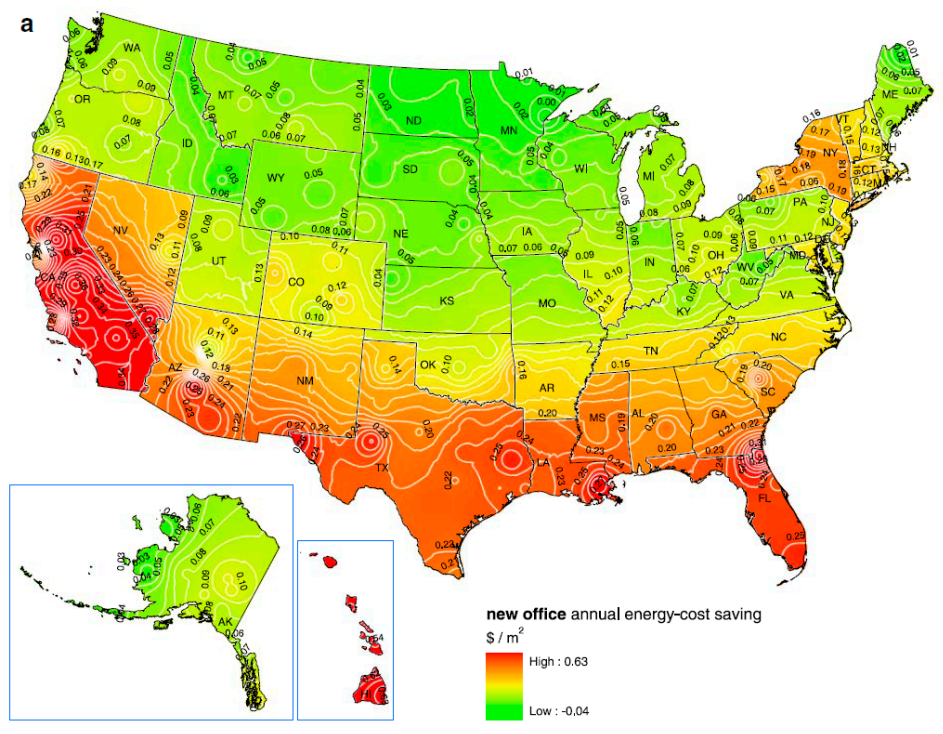

Figure 8. Annual net energy cost savings with reflective roofs compared to black roofs presented as $\$ / \mathrm{m}^{2}$ of roof area for new offices in the US. Reproduced from [23], Springer, 2007.

\subsection{School Building}

The summary annual energy cost savings results for the reference school building are presented in Figure 9. The school and the office buildings have different geometries, solar gains and occupancy schedules, therefore their load profiles are different and the effect of roof reflectivity and insulation slightly varies. Phoenix, Los Angeles and Miami show the highest benefits with reflective roofs, but even Boulder achieves annual savings higher than $\$ 0.32 / \mathrm{m}^{2}$ for less insulated roofs and $\$ 0.12 / \mathrm{m}^{2}$ for highly insulated roofs. Note that, for this building type, if the roof is well insulated, the savings are similar for most locations (that was not the case for the office building). Reflective roofs result in no overall energy cost penalties for any climatic zone. A closer look at the heating-dominated climate of Minneapolis is shown in Figure 10. Similar to the results of Figure 6 for the box retail building, increased insulation levels reduce the total energy demand. Nevertheless, the impact of roof reflectivity is significant for all insulation levels.

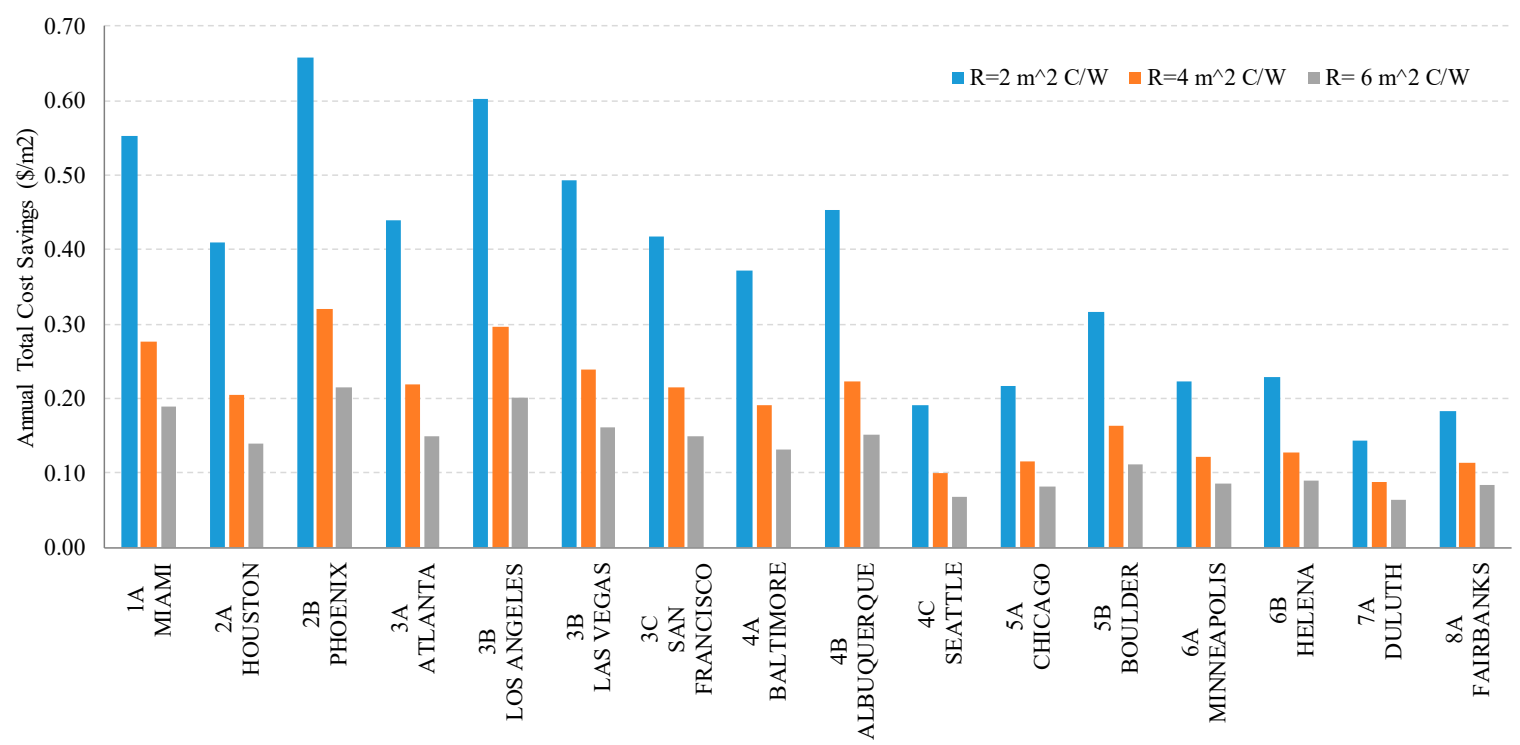

Figure 9. Annual energy cost savings (per unit roof area) with a new reflective roof (70\% reflectivity) versus a black roof (6\% reflectivity) for the school building with three roof insulation levels in all 16 climatic locations. 


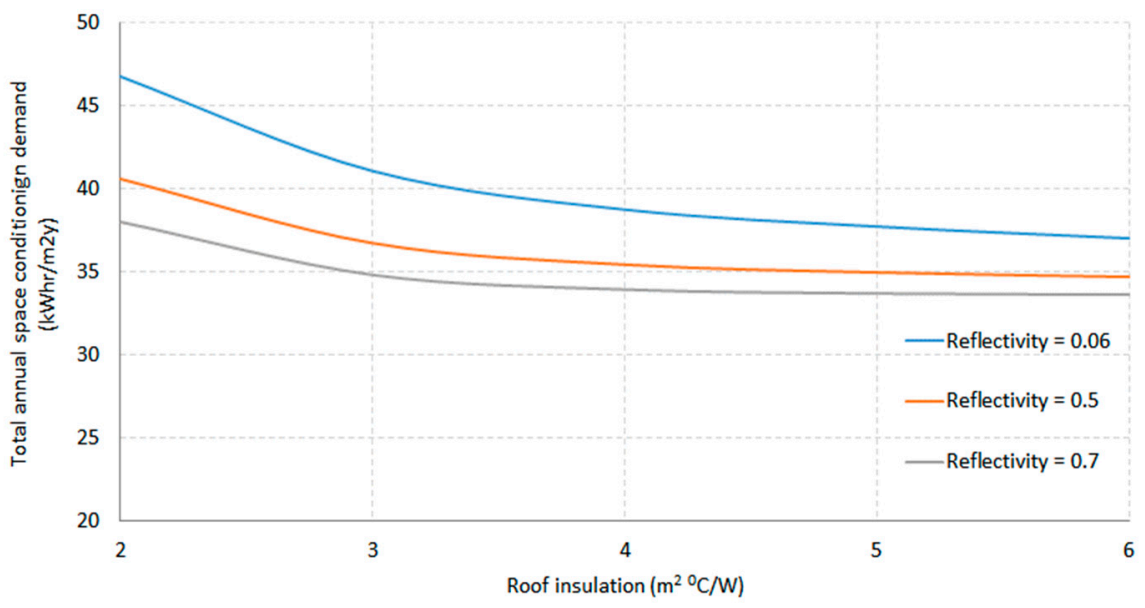

Figure 10. Variation of total annual heating and cooling demand of a school building with a black roof, aged reflective roof and new reflective roof as a function of roof insulation in Minneapolis.

\section{Flexible (Mechanically Attached) Reflective Roof Systems}

The last part of this study considered the performance of flexible (attached) reflective roofing systems compared to adhered roofs. Mechanically attached roofs is a different type of construction which can be affected by indoor air intrusion into the roof system, caused by wind-induced pressure differences over the roof and air permeability of the roof components underneath the roofing membrane. The flexible membrane is allowed to flutter, drawing air from the space towards the interior side of the membrane, through joints and perforations (Figure 11). The air exchanges heat with the roof surface (which is usually at a quite different temperature) and needs to be reconditioned when it circulates back into the space. That may reduce the energy performance of mechanically attached roofs. Other considerations about moisture accumulation with this type of reflective roof in cold climates also exist and need careful attention [45].

Molleti et al. [46] found that deflection of mechanically attached roofs increases with membrane width, irrespective of the membrane type. For similar sheet widths, thermoset membrane (EPDM) had higher deflection compared to the thermoplastic membrane (TPO). To minimize the air intrusion into the roof assembly, an air retarder is suggested at the warm side of the roofing assembly, although penetrations will reduce its effectiveness. In a successive study [47], the authors reported that, with an air retarder, irrespective of the assembly type and configuration, the volume of air intrusion can be reduced by more than $50 \%$.

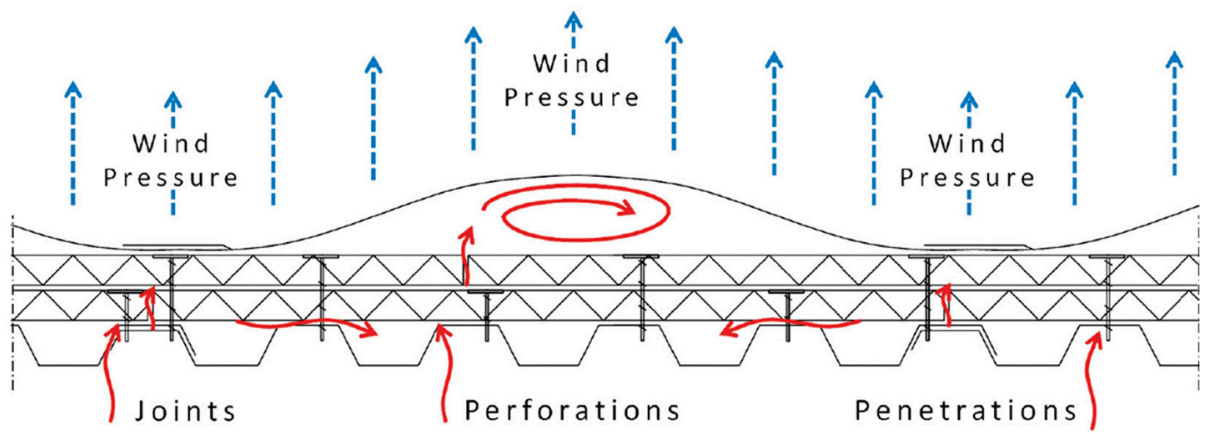

Figure 11. Membrane fluttering due to wind uplifting, resulting in pressure difference and indoor air intrusion below the roof membrane. Reproduced from [48], IIBEC, 2014.

A comprehensive study of the effect of air intrusion on energy use with mechanically attached roofing systems was conducted by Pallin et al. [48]. The study considered climate (temperature, wind speed, and solar radiation levels), roof reflectivity, indoor set point 
temperature, and air permeability of roof components (below the membrane) to investigate the effect of all these parameters on potential energy penalties due to air intrusion in mechanically attached roofs. Hourly wind speeds were also used to predict wind gusts that affect the fluttering of the roof. The air pressure at the interior of the roof membrane was then calculated as a function of wind speed and weight of the surface membrane. The air flow rate into the roofing assembly was computed from the pressure difference and the air leakage coefficient. These effects were dynamically modeled using the validated tool WUFI $[49,50]$, to model a building with a typical steel deck and a mechanically attached roofing system over the entire year for climatic zones 4-7. The results showed that air intrusion has a larger relative energy penalty for reflective roofs than dark-colored roofs for all climatic zones. For normal air leakage rates, reflective roofs may result in $1-3 \%$ energy losses compared to adhered systems, while dark-colored roofs will not result in losses higher than $1 \%$. For roofs with higher air leakage, reflective membranes may cause up to $4 \%$ more energy losses in cold climates compared to black roofs.

To compare with these results, our EnergyPlus reference model of the big box retail store was modified to account for the presence of a mechanically attached roof. The model was modified to account for air intrusion according to the model presented by [48]. In EnergyPlus, this was modeled with an additional infiltration rate to the room air, equivalent to the heat loss/gain from the air intrusion described in the WUFI model. Different leakage rates were simulated in the model.

Figure 12 presents the results expressed as the relative increase in energy losses with a reflective, mechanically attached roof compared to a reflective adhered roof system, as a function of roof insulation for Chicago (climate zone 5). Our results agree with the previous study by Pallin et al. [48], i.e., reflective mechanically attached roofs will result in relative energy losses around 3\% compared to reflective adhered roofs for normal roof leakage rates, slightly increasing for higher insulation levels. In addition, the relative energy penalty with black mechanically attached roofs is slightly lower (by 1-3\%) for cold climates, depending on actual air leakage rates.

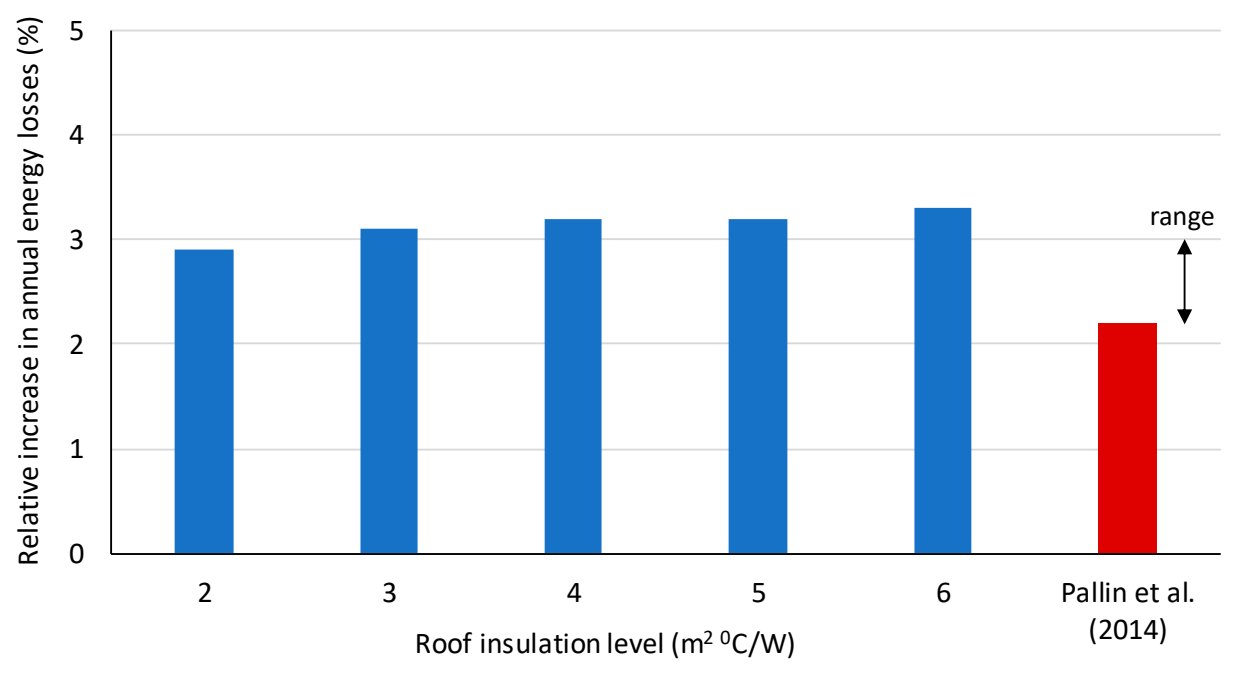

Figure 12. Relative increase in energy losses (compared to adhered systems) with a reflective mechanically-attached roof for the big box retail reference building in Chicago.

\section{Conclusions}

This paper presents an extensive modeling study to investigate the potential benefits of reflective roofs in different US climates as a function of roof insulation for adhered and attached roof systems. The combined impact of roof reflectivity and insulation level on annual energy cost for space conditioning was studied for three building types (retail, office, and school buildings) in 16 US climatic zones using TMY3 weather files, including 
mixed and cold climates, to clarify issues that have been reported with mixed results from available simplified tools.

DOE reference buildings for the three building types were modeled with EnergyPlus to obtain reliable results without using significant assumptions. The 16 selected locations represent the most representative climates in the US, with the highest number of buildings in each location. For each selected location and building type, the roof reflectivity was varied between $6 \%$ (black), $50 \%$ (aged reflective roof), and 70\% (new reflective roof). At the same time, roof insulation levels were varied between 2 and $6.13 \mathrm{~m}^{2}{ }^{\circ} \mathrm{C} / \mathrm{W}$ to cover under-insulated and well-insulated roof systems. The annual energy demand and energy costs for the 720 studied cases with adhered roof systems showed that:

- In all cases, energy savings with reflective roofs (compared to black roofs) are higher for warm climates, as expected, but do not necessarily follow the order of climatic sub-categories due to the combined effects of solar radiation, outside temperature, and building characteristics.

- Roof reflectivity and roof insulation both play an important role for all climatic zones. Different building types have different thermal load profiles and therefore the effects of roof reflectivity and insulation vary. Roof insulation is critical for all climates. The impact of roof reflectivity is equally important for warm climates. Maximum overall energy cost benefits are observed when the roof is sufficiently insulated. Meeting or exceeding code requirements is recommended.

- Overall, adhered reflective roofs result in no energy penalties except for climate zones $7-8$. For zones 5 and 6 , the benefits of reflective roofs (compared to black roofs) are lower but still evident. Previous claims concerning the negative impact of cool roofs in mixed and cold climates based on data obtained from roof calculators are not justified. Decision makers need to consider insulation levels, membrane durability performance, and attachment factors when assessing the overall performance of reflective roofs in cold climates.

- For box retail stores, reflective roofs have positive effects on the annual energy demand and cost up to climate zone 6 . Phoenix shows the highest annual energy savings (per roof unit area) of $\$ 0.48 \$ / \mathrm{m}^{2}$ followed by Miami, Houston, and Los Angeles. Wellinsulated roofs $\left(\mathrm{R}=6.13 \mathrm{~m}^{2}{ }^{\circ} \mathrm{C} / \mathrm{W}\right)$ also present noticeable savings if reflective, in the order of $\$ 0.16 / \mathrm{m}^{2}$ up to climate zone 4 . Reflective roofs may result in small energy penalties only in very cold climates (zones 7-8) for this building type. For warm climates, the performance of a well-insulated cool roof cannot be matched by installing additional insulation on a black roof.

- For low-rise office buildings, that have higher window areas and internal gains, reflective roofs show benefits for all climatic zones. The annual costs savings per roof unit area are more significant in this case, especially in climatic zones 1-4, but can reach $\$ 0.215 / \mathrm{m}^{2}$ even for zones $5-6$.

- For school buildings, there are no overall energy or cost penalties with reflective roofs for any location or climatic zone. Phoenix, Los Angeles, and Miami show the highest benefits, but even Boulder, Colorado achieves annual savings higher than $\$ 0.32 / \mathrm{m}^{2}$ for poorly insulated roofs.

- Roof aging and reduced reflectivity (to around 50\%) may reduce reflective roof savings by $20 \%$, but savings are still significant compared to black roofs for climate zones 1-4 and lower for zones 5-6.

- Mechanically attached (flexible) reflective roofs may result in up to 3\% relative energy losses (compared to adhered systems) for the climate of Chicago. Dark-colored roofs achieve slightly $(1-3 \%)$ better performance for this roof construction, especially for cold climates.

- Long-term durability and waterproofing performance are always important in the selection of a roofing membrane and assembly type for any roof reflectivity and climate.

Finally, this work was conducted using TMY3 climatic data files, which consider statistically processed data until 2005. In view of climate change, future research should evaluate 
the performance and benefits of cool roofs using the most recent climate files [51,52] and future predictions of climate based on the latest projections. Considering global warming, the role of cool materials and roofs will be even more evident and important.

Author Contributions: Conceptualization, A.T. and S.L.; methodology, S.L.; software, S.L.; analysis, A.T.; writing—original draft preparation, A.T.; writing—review and editing, A.T. and S.L.; supervision, A.T.; project administration, A.T. All authors have read and agreed to the published version of the manuscript.

Funding: The authors would like to thank the Center for High Performance Buildings at Purdue University for supporting this work.

Institutional Review Board Statement: Not applicable.

Informed Consent Statement: Not applicable.

Data Availability Statement: The data presented in this study are available on request from the corresponding author.

Acknowledgments: The authors would like to thank J. Jannash from Firestone Building Products and A. Maranabasari from Purdue University for assisting with literature review and research studies categorization.

Conflicts of Interest: The authors declare no conflict of interest. The funders had no role in the design of the study; in the collection, analyses, or interpretation of data; in the writing of the manuscript, or in the decision to publish the results.

\section{References}

1. Santamouris, M.; Synnefa, A.; Karlessi, T. Using advanced cool materials in the urban built environment to mitigate heat islands and improve thermal comfort conditions. Sol. Energy 2011, 85, 3085-3102. [CrossRef]

2. Santamouris, M.; Cartalis, C.; Synnefa, A.; Kolokotsa, D. On the impact of urban heat island and global warming on the power demand and electricity consumption of buildings-A review. Energy Build. 2015, 98, 119-124. [CrossRef]

3. Santamouris, M.; Synnefa, A.; Kolokotsa, D.; Dimitriou, V.; Apostolakis, K. Passive cooling of the built environment-use of innovative reflective materials to fight heat islands and decrease cooling needs. Int. J. Low-Carbon Technol. 2008, 3, 71-82. [CrossRef]

4. Akbari, H.; Konopacki, S. Energy effects of heat-island reduction strategies in Toronto, Canada. Energy Build. 2004, 29, 191-210. [CrossRef]

5. Santamouris, M. Cooling the cities-A review of reflective and green roof mitigation technologies to fight heat island and improve comfort in urban environments. Sol. Energy 2014, 103, 682-703. [CrossRef]

6. Synnefa, A.; Saliari, M.; Santamouris, M. Experimental and numerical assessment of the impact of increased roof reflectance on a school building in Athens. Energy Build. 2012, 55, 7-15. [CrossRef]

7. Synnefa, A.; Santamouris, M.; Apostolakis, K. On the development, optical properties and thermal performance of cool colored coatings for the urban environment. Sol. Energy 2007, 81, 488-497. [CrossRef]

8. Levinson, R.; Akbari, H.; Konopacki, S.; Bretz, S. Inclusion of cool roofs in nonresidential Title 24 prescriptive requirements. Energy Policy 2005, 33, 151-170. [CrossRef]

9. Akbari, H.; Levinson, R.; Rainer, L. Monitoring the energy-use effects of cool roofs on California commercial buildings. Energy Build. 2005, 37, 1007-1101. [CrossRef]

10. Kolokotsa, D.; Diakaki, C.; Papantoniou, S.; Vlissidis, A. Numerical and experimental analysis of cool roofs application on a laboratory building in Iraklion, Crete, Greece. Energy Build. 2012, 55, 85-93. [CrossRef]

11. Tengfang, X.; Sathaye, J.; Akbari, H.; Gargc, V.; Tetali, S. Quantifying the direct benefits of cool roofs in an urban setting: Reduced cooling energy use and lowered greenhouse gas emissions. Build. Environ. 2012, 48, 1-6.

12. Bozonnet, E.; Doya, M.; Allard, F. Cool roofs impact on building thermal response: A French case study. Energy Build. 2011, 43, 3006-3012. [CrossRef]

13. Kolokotroni, M.; Gowreesunker, G.L.; Girisharan, R. Cool roof technology in London: An experimental and modelling study. Energy Build. 2013, 67, 658-667. [CrossRef]

14. Romeo, C.; Zinzi, M. Impact of a cool roof application on the energy and comfort performance in an existing non-residential building. A Sicilian case study. Energy Build. 2013, 67, 647-657. [CrossRef]

15. Boixo, S.; Diaz-Vicente, M.; Colmenar, A.; Castro, M. Potential energy savings from cool roofs in Spain and Andalusia. Energy 2012, 38, 425-438. [CrossRef]

16. Saber, H. Hygrothermal performance of cool roofs with reflective coating material subjected to hot, humid and dusty climate. J. Build. Phys. 2021, in press. [CrossRef] 
17. Mastrapostoli, E.; Karlessi, T.; Pantazaras, A.; Kolokotsa, D.; Gobakis, K.; Santamouris, M. On the cooling potential of cool roofs in cold climates: Use of cool fluorocarbon coatings to enhance the optical properties and the energy performance of industrial buildings. Enegry Build. 2014, 69, 417-425. [CrossRef]

18. Akbari, H.; Konopacki, S. The impact of reflectivity and emissivity of roofs on building cooling and heating energy use. In Proceedings of the Thermal Performance of the Exterior Envelopes of Buildings VII, Clearwater, FL, USA, 6-10 December 1998.

19. Konopacki, S.; Akbari, H. Measured Energy Savings and Demand Reduction from a Reflective Roof Membrane on a Large Retail Store in Austin; Report LBNL-47149; Lawrence Berkeley National Laboratory: Foshan, China, 2001.

20. ERA. EPDM Roofing Association: Analysis of Berkeley Labs Study Details Flawed Science. 2014. Available online: https: / / facilityexecutive.com/2014/02/analysis-berkeley-labs-study-details-flawed-science (accessed on 28 September 2021).

21. Sproul, J.; Wan, W.P.; Mandel, B.H.; Rosenfeld, A.H. Economic comparison of white, green, and black flat roofs in the United States. Energy Build. 2014, 71, 20-27. [CrossRef]

22. Ibrahim, S. Black versus White: Energy Performance and Cold Climate Concerns. In Proceedings of the International Roofing Expo conference, Orlando, FL, USA, 22-24 February 2012.

23. Levison, R.; Akbari, H. Potential benefits of cool roofs on commercial buildings: Conserving energy, saving money, and reducing emission of greenhouse gases and air pollutants. Energy Effic. 2010, 3, 53-109. [CrossRef]

24. Taylor, T.J.; Hartwig, C. Cool Roof Use in Commercial Buildings in the United States: An Energy Cost Analysis. ASHRAE Trans. 2018, 124, 88-95.

25. Hosseini, M.; Akbari, H. Heating energy penalties of cool roofs: The effect of snow accumulation on roofs. Adv. Build. Energy Res. 2014, 8, 1-13. [CrossRef]

26. Graveline, S.P. Still Cool After All These Years: White Reflective Roofing Stands Up to Scientific Scrutiny. Available online: https: / / vinylroofs.org/wp-content/uploads/2019/10/CoolRoofWhitePaper-WhiteReflectiveRoofingStandsUptoScientificScrutiny.pdf (accessed on 28 September 2021).

27. ORNL: Oak Ridge National Laboratory, 2015. DOE Cool Roof Calculator. 2015. Available online: https://web.ornl.gov/sci/ buildings/tools/cool-roof/ (accessed on 28 September 2021).

28. Pearson, C. Are Cool Roofs Green? The Answer's not Black and White. Environmental Building News. 29 June 2014. Available online: https:/ / www2.buildinggreen.com/article/are-cool-roofs-green-answer-s-not-black-and-white (accessed on 28 September 2021).

29. Reale, R. A White Roof Isn't Always the Right Roof. Pacific Standard Magazine. May 2009. Available online: http:/ /www.psmag. com/business-economics/white-roof-isnt-always-right-roof-3711 (accessed on 28 September 2021).

30. ORNL: Oak Ridge National Laboratory. Roof Savings Calculator. currently unavailable online; 2016. Available online: http: / / rsc.ornl.gov/ (accessed on 3 November 2021).

31. Tyler, C.A. Rethinking Cool Roofs-Evaluating Effectiveness of White Roofs in Northern Climates; Construction Specifier-The Official Magazine of Construction Specification Institute, 30 November 2013. Available online: https: / /www.constructionspecifier. $\mathrm{com} /$ rethinking-cool-roofing-evaluating-effectiveness-of-white-roofs-in-northern-climates-2/ (accessed on 28 September 2021).

32. Pearce, D. The Truth about Energy Saving Roofs: Reflective Roofs. Facility Executive. August 2014. Available online: http: / / facilityexecutive.com/2014/08/ reflective-roofs (accessed on 28 September 2021).

33. Mellot, J.W.; New, J.R.; Sanyal, J. Preliminary Analysis of Energy Consumption for Cool Roofing Measures. RCI Interface Tech. J. 2013, 31, 25-36.

34. Freund, S.; Dettmers, D.J.; Reindl, D.T. Simulated Influence of Roof Reflectance on the Building Energy Balance in Two Northern Cities. ASHRAE Trans. 2006, 112, 171-180.

35. Desjarlais, A.; Miller, W.; Shrestha, S. Trading Off Cool Roofs for Insulation; Oak Ridge National Laboratory: Oak Ridge, TN, USA, 2012.

36. Paolini, R.; Zinzi, M.; Poli, T.; Carnielo, E.; Mainini, A.G. Effect of ageing on solar spectral reflectance of roofing membranes: Natural exposure in Roma and Milano and the impact on the energy needs of commercial buildings. Energy Build. 2014, 84, 333-343. [CrossRef]

37. ASHRAE, 2017. ANSI/ASHRAE/IES Standard 90.1-2017-Energy Standard for Buildings Except Low-Rise Residential Buildings; American Society of Heating, Refrigerating and Air-Conditioning Engineers: Atlanta, GA, USA, 2017.

38. Hosseini, M.; Leea, B.; Vakilinia, S. Energy performance of cool roofs under the impact of actual weather data. Energy Build. 2017, 145, 284-292. [CrossRef]

39. Ramamurthy, P.; Sun, T.; Rule, K.; Bou-Zeid, E. The joint influence of albedo and insulation on roof performance: An observational study. Energy Build. 2015, 93, 249-258. [CrossRef]

40. EnergyPlus. 2021. Available online: https:/ / energyplus.net (accessed on 28 September 2021).

41. EIA. US Energy Prices; Energy Information Administration, United States Department of Energy: Washington, DC, USA, 2012.

42. United States Department of Energy, 2015. Commercial Reference Buildings. 2015. Available online: http://energy.gov/eere/ buildings/commercial-reference-buildings (accessed on 28 September 2021).

43. NREL, National Renewable Energy Laboratory. U.S. Department of Energy Commercial Reference Building Models of the National Building Stock; Technical Report NREL/TP-5500-46861; National Renewable Energy Laboratory: Washington, DC, USA, 2001.

44. Akbari, H.; Berhe, A.A.; Levinson, R.; Graveline, S.; Foley, K.; Delgado, A.H.; Paroli, R.M. Aging and Weathering of Cool Roofing Membranes; Lawrence Berkeley National Laboratory: Foshan, China, 2006. 
45. Kehrer, M.; Pallin, S. Condensation Risk of Mechanically Attached Roof Systems in Cold-Climate Zones. RCI International Convention and Trade Show, March 2013.

46. Molleti, S.; Baskaran, B.A.; Ko, S.; Beaulieu, P. Air Intrusion vs Air Leakage-The dilemma for low-sloped, mechanically attached membrane roofs. In Proceedings of the Canadian Symposium on Roofing Technology, Toronto, ON, USA, 16 March 2009; pp. 1-9.

47. Molleti, S.; Baskaran, B.A.; Kalinger, P.; Beaulieu, P. Air Intrusion and its impact on the Moisture Transport in Mechanically Attached Roofing Systems. In Proceedings of the 2011 International Roofing Symposium, Washington, DC, USA, 7-9 September 2011.

48. Pallin, S.; Kehrer, M.; Desjarlais, A. The Energy Penalty associated with the Use of Mechanically Attached Roofing Systems. In Proceedings of the 2014 Symposium on Building Envelope Technology, Tampa, FL, USA, 20-21 October 2014.

49. Karagiozis, A.; Künzel, H.M.; Holm, A. WUFI-ORNL/IBP-A North American Hygrothermal Model. In Proceedings of the Performance of Exterior Envelopes of Whole Buildings VIII-Moisture Model Inputs: Principles, Clearwater Beach, FL, USA, 2-7 December 2001; pp. 1-10.

50. Künzel, H.M.; Schmidt, T.; Holm, A. Exterior Surface Temperature of Different Wall Constructions: Comparison of Numerical Simulation and Experiment. In Proceedings of the 11th Symposium for Building Physics, Dresden, Germany, 26-30 September2002; pp. 441-449.

51. Climate Change Weather File Generator; Energy and Climate Change Division, University of Southampton. 2020. Available online: https: / / energy.soton.ac.uk/ climate-change-world-weather-file-generator-for-world-wide-weather-data-ccworldweathergen/ (accessed on 4 November 2021).

52. TMYx Weather Data. Available online: https://climate.onebuilding.org/ (accessed on 3 November 2021). 